\title{
Triploid (sterile) farmed Atlantic salmon males attempt to spawn with wild females
}

\author{
P. G. Fjelldal ${ }^{1, *}$, V. Wennevik ${ }^{2}$, I. A. Fleming ${ }^{3}$, T. Hansen ${ }^{1}$, K. A. Glover ${ }^{2}$ \\ ${ }^{1}$ Institute of Marine Research, Matre Aquaculture Research Station, 5984 Matredal, Norway \\ ${ }^{2}$ Institute of Marine Research, PO Box 1870, Nordnes, 5817 Bergen, Norway
}

${ }^{3}$ Fish Evolutionary Ecology Research Group and Department of Ocean Sciences, Memorial University of Newfoundland, St. John's, Newfoundland and Labrador A1C 5S7, Canada

\begin{abstract}
Genetic interaction between farmed escapees and wild conspecifics represents one of the major environmental challenges faced by the Atlantic salmon aquaculture industry. In order to mitigate genetic interactions, triploid (sterile) farmed fish can be produced. However, triploids may still develop secondary sexual characteristics, and potentially attempt to spawn with wild fish. Here, triploid farmed salmon males were placed into 2 spawning arenas containing either a wild and a farmed female, or a wild and a farmed female and wild males. Qualitative observations demonstrated that triploid male Atlantic salmon displayed the full range of spawning behaviors of wild males, and stimulated the wild female to spawn in the absence of wild males. Quantitative aspects of the observed behaviors, such as their frequency among triploid males and the competitive ability of farmed triploid males compared with diploid farmed and wild males, require investigation before full-scale production of triploid salmon is initiated commercially.
\end{abstract}

KEY WORDS: Mating behavior · Aquaculture $\cdot$ Genetic interaction · Farmed escapees · Mitigation • Triploidy

\section{INTRODUCTION}

The Atlantic salmon Salmo salar L. aquaculture industry has displayed rapid and almost continual growth from its initiation in the early 1970s to the present day (FAO 2013). In Norway, the world's largest producer of farmed Atlantic salmon, this production has risen from 94 tons in 1971 to over 1 million tons in 2011. However, the expansion of this industry has not been without significant environmental problems. Among several other challenges, farmed escapees and their potential interactions with wild conspecifics have attracted considerable attention (Naylor et al. 2005, Jonsson \& Jonsson 2006, Ferguson et al. 2007).

Each year, tens of thousands and in some cases even hundreds of thousands of farmed salmon are reported to escape from their net pens (Anonymous

${ }^{*}$ Corresponding author: pergf@imr.no
2007, 2012, Thorstad et al. 2008). While many of these escapees are never seen again, some enter rivers inhabited by wild salmon populations (Milner \& Evans 2003, Fiske et al. 2006, Walker et al. 2006, Morris et al. 2008), even outnumbering them on the spawning grounds in some rivers in some years (Fiske et al. 2006). The relative spawning success of farmed salmon is lower than that of wild fish (Fleming et al. 1996, 2000); however, farmed escapees have been observed spawning with wild salmon in the natural environment (Lura \& Saegrov 1991, Webb et al. 1991, Saegrov et al. 1997, Butler et al. 2005). As a consequence of farmed fish successfully spawning, genetic changes in the allele frequencies of molecular-genetic markers in native populations have been documented in rivers in Norway (Skaala et al. 2006, Glover et al. 2012, 2013), Ireland (Crozier 1993, Clifford et al. 1998) and North America (Bourret et al.

() The authors 2014. Open Access under Creative Commons by Attribution Licence. Use, distribution and reproduction are unrestricted. Authors and original publication must be credited. 
2011). More recently, the level of introgression has also been quantified, revealing up to $47 \%$ introgression in some Norwegian rivers (Glover et al. 2013).

Wild Atlantic salmon are genetically structured into more or less defined populations, and may also display genetic differences to each other in fitnessrelated traits. Some of these differences potentially reflect adaptations to their natal rivers (Taylor 1991, Garcia de Leaniz et al. 2007). In contrast, farmed Atlantic salmon in Norway have been subject to domestication selection since the start of the aquaculture industry in the early 1970s (Gjedrem et al. 1991), and are at present approximately in their 10th generation. As a result of domestication, farmed salmon display a range of genetic differences to wild salmon, including: growth (Glover et al. 2009, Solberg et al. 2013), behavior (Fleming \& Einum 1997), gene-expression patterns (Roberge et al. 2006, Solberg et al. 2012) and allele frequencies of putatively neutral (Skaala et al. 2004) and putatively nonneutral genetic markers (Karlsson et al. 2011). Furthermore, the offspring of farmed salmon display reduced survival in the wild when compared with wild salmon (Fleming et al. 2000, McGinnity et al. 2003, Skaala et al. 2012). Thus, it follows that there are scientific grounds for concern regarding the genetic integrity of native populations where farmed escapees are observed and potentially reproduce.

Technological advances have improved the robustness of commercial fish farms to escapes (Jensen et al. 2010). Other measures to reduce the number of escapees, such as using DNA tracing methods to identify the source of origin for unreported escapees (Glover et al. 2008, Glover 2010), have also been implemented. Nevertheless, farmed salmon continue to escape into the wild, and other mitigation measures, such as removal of escapees from the spawning grounds and/or removal of the ability to reproduce through sterilization of farmed salmon, need to be considered. Recent work on the performance of triploid (sterile) farmed salmon in commercial production has been promising (Taylor et al. 2013, Fraser et al. 2013), and the Norwegian industry is taking the lead by making triploid salmon eggs commercially available (T. Hansen pers. obs.). However, although triploid Atlantic salmon are effectively $100 \%$ sterile, some males still mature sexually with gonadosomatic indices similar to those of mature diploid males (Cotter et al. 2000). Moreover, escaped triploid farmed males have been documented to migrate back into rivers post-escape (Cotter et al. 2000). Consequently, they display the potential to disrupt natural reproduction by partaking in spawning with fertile wild females.
In Atlantic cod Gadus morhua (Feindel et al. 2010) and Masu salmon Oncorhynchus masou (Kitamura et al. 1991), triploid males have been demonstrated to attempt to spawn with sexually functional diploid conspecifics. In Atlantic salmon, however, the spawning behavior of triploid fish has not been investigated in either sex. Thus, the aim of the present study was to perform a qualitative analysis of spawning behavior of triploid farmed Atlantic salmon males. Two primary questions were posed. (1) Do triploid male salmon that have developed secondary sexual characteristics display any of the known spawningrelated behaviors (Fleming 1996), and ultimately attempt to spawn with wild female salmon? (2) Are wild female salmon willing to spawn with triploid sterile males? In order to address these 2 questions, spawning experiments involving triploid farmed males, diploid farmed females, and wild females and males were conducted in 2 semi-natural spawning channels.

\section{MATERIALS AND METHODS}

\section{Wild and farmed salmon}

Wild salmon spawners (2 females and 2 males) were collected from the River Figgjo in southwestern Norway in the autumn of 2011. Fish were captured in the river by angling, and transported to the Institute of Marine Research experimental facility in Matre in October 2011. All wild fish were selected based upon the external morphology, but were verified as wild (as opposed to being farmed escapees) based upon scale reading (Lund \& Hansen 1991).

The farmed fish used in this study were 2-sea winter mature triploid males $(\mathrm{n}=10)$ and diploid females $(\mathrm{n}=2)$ produced as under-yearling smolts and transferred to seawater in October 2009. They originated from a mixture of eggs from 3 females that were fertilized with a mix of sperm from 3 males; both sexes were from the commercial Aquagen strain. After fertilization at $8^{\circ} \mathrm{C}$ for $37 \mathrm{~min} 30 \mathrm{~s}$, half of the eggs were subjected to a hydrostatic pressure of 655 bar for 6 min $15 \mathrm{~s}$ (TRC-APV, Aqua Pressure Vessel, TRC Hydraulics), giving 2 groups, 1 triploid and 1 diploid. The fish were reared in separate units until seawater transfer, when they were tagged with passive integrated transponders and transferred to one $5 \times 5 \mathrm{~m}$ sea-cage. The fish were kept in the sea-cage under natural light and standard feeding conditions until the start of the experiment. 


\section{Experimental facilities and design}

The experiment was conducted in spawning arenas that were designed specifically for this study. They consisted of two $7 \mathrm{~m}$ diameter outdoor tanks converted into replicate spawning channels by placing a $3 \mathrm{~m}$ diameter tank upside down into the middle of each $7 \mathrm{~m}$ tank to create an approximately $2 \mathrm{~m}$ wide by $50 \mathrm{~cm}$ deep raceway around the edge of the tank (approximately $31 \mathrm{~m}^{2}$ ). Each raceway was then filled to a depth of $50 \mathrm{~cm}$ with gravel typical of that used by Atlantic salmon for spawning. Finally, the water level was adjusted to ca. $70 \mathrm{~cm}$ deep, as measured from the gravel surface, in order to mimic conditions in which Atlantic salmon spawn in the wild (Fleming 1996). These tanks were designed based on those successfully implemented in previous studies to quantify the relative spawning success of farmed and wild Atlantic salmon (e.g. Fleming et al. 1996), and are hereafter referred to as Arenas 1 and 2.

Prior to starting the experiment on 15 November 2011, the mass, length and any development of secondary sexual characteristics were recorded for all wild and farmed salmon. At the same time, each fish was individually tagged by a colour disc placed on the upper back of the fish (Fleming et al. 1996), which permitted its visual identification in the 2 spawning arenas. Fish were sedated with $0.1 \mathrm{~g} \mathrm{l}^{-1}$ Finquel vet. (Scanvacc) prior to handling and were thereafter placed into their respective spawning arenas ready for observation.

Arena 1 contained 1 diploid mature wild female, 1 diploid farmed female, and 4 triploid mature farmed males. Arena 2 contained 2 diploid mature wild males, 1 diploid mature wild female, 1 diploid mature farmed female, and 2 triploid mature farmed males.

On 18 November, 2 additional farmed triploid males were released into each spawning arena, and the ovulation status of the females was checked.

\section{Behavioral observations}

The spawning arenas were monitored continuously by visual observation from 08:00 to $16: 00 \mathrm{~h}$ and from 19:00 to 19:30 h daily from 15 to 21 November 2011.

A single video camera was mounted in each arena. Arena 1 had a camera mounted on 16 November and Arena 2 had a camera mounted on 17 November. The positions of the cameras were selected in order to film spawning behavior and were repositioned as the females changed 'spawning position'. Filming was continuous and the recordings were reviewed for spawning behaviors after the study was terminated on 21 November, when the wild female in Arena 1 had released her eggs. Behaviors were categorized into 3 main types: (1) agonistic prior to and during spawning (including aggression, displays and submission), (2) courting and preparatory acts (including courting, quivering and digging), and (3) spawning (including oviposition and ejaculation) (behaviors described in detail in Fleming et al. 1996).

\section{Validation of triploid status post-termination}

On 24 November, a blood sample was collected from each of the experimental fish and used subsequently to determine red blood cell diameter in order to verify ploidy status. Samples were also collected from 10 mature diploid farmed males from the same stock as the mature triploid males for the same purpose. A blood smear was made from each individual. The diameters of 20 red blood cells were measured (Image-Pro Plus, version 4.0, Media Cybernetics) on each blood smear. There was no overlap in mean red blood cell diameter between diploid (mean $16.4 \mu \mathrm{m}$, range 15.3 to $17.3 \mu \mathrm{m}$ ) and triploid (mean $19.4 \mu \mathrm{m}$, range 18.7 to $20.6 \mu \mathrm{m}$ ) individuals.

\section{RESULTS}

The fish were stocked into the spawning arenas at 12:00 h on 14 November (referred to as Day 0). All males, both wild and farmed, had running milt, and all females had ovulated. In the following section we describe the first days of the study period in more detail than the last days in order to focus on (1) how the fish established themselves in the habitat, and (2) their subsequent spawning behavior. The identity (sex/ploidy/fish no.) of the experimental fish is shown in Table 1.

\section{Timeline for behavioral observations}

15 November (Day 1). In Arena 1, there was considerable aggressive behavior (Fig. 1) between the triploid males in the morning. This seemed to correspond with the onset of nesting activity (digging) by the wild female (Fish 1) at 11:30 h (Fig. 2A). The amount of male aggression decreased during the day, and the males became calmer and showed increased courting behavior, while the wild female 
Table 1. Size and red blood cell diameters of the experimental fish, as well as a summary of their spawning behaviors, and occurrence of retained eggs in females. Male aggression in Arena 1 included long periods of fighting and biting, while the male aggression in Arena 2 was much milder and was mostly chasing and displays. nd: not determined

\begin{tabular}{|c|c|c|c|c|c|c|c|c|c|c|}
\hline & Ploidy & $\begin{array}{l}\text { Fish } \\
\text { no. }\end{array}$ & $\begin{array}{l}\text { Length } \\
\text { (cm) }\end{array}$ & $\begin{array}{l}\text { Mass } \\
(\mathrm{g})\end{array}$ & $\begin{array}{l}\text { Red blood cell } \\
\text { diameter }(\mu \mathrm{m})\end{array}$ & $\begin{array}{l}\text { Nesting } \\
\text { behavior }\end{array}$ & $\begin{array}{l}\text { Courting } \\
\text { behavior }\end{array}$ & $\begin{array}{c}\text { Aggressive } \\
\text { behavior }\end{array}$ & $\begin{array}{l}\text { Spawned } \\
\text { eggs }\end{array}$ & Retained \\
\hline \multicolumn{11}{|l|}{ Arena 1} \\
\hline Wild female & Diploid & 1 & 75 & nd & 17.4 & Yes & - & No & Yes & No \\
\hline Farmed female & Diploid & 2 & 74 & 5.0 & 16.7 & No & - & No & No & Yes \\
\hline Farmed male & Triploid & 3 & 83 & 5.4 & 18.7 & - & Yes & Yes & - & - \\
\hline Farmed male & Triploid & 4 & 83 & 5.3 & 19.4 & - & Yes & Yes & - & - \\
\hline Farmed male & Triploid & 5 & 77 & 4.4 & 19.1 & - & No & No & - & - \\
\hline Farmed male & Triploid & 6 & 79 & 4.8 & 18.7 & - & Yes & Yes & - & - \\
\hline Farmed male ${ }^{a}$ & Triploid & 7 & 87 & nd & 20.6 & - & Yes & Yes & - & - \\
\hline Farmed male $^{\mathrm{a}}$ & Triploid & 8 & 82 & nd & 20.1 & - & Yes & Yes & - & - \\
\hline \multicolumn{11}{|l|}{ Arena 2} \\
\hline Wild female & Diploid & 9 & 75 & nd & 17.6 & Yes & - & No & Yes & No \\
\hline Farmed female & Diploid & 10 & 80 & 6.9 & 16.2 & Yes & - & No & Yes & No \\
\hline Wild male & Diploid & 11 & 80 & 4.2 & 16.5 & - & Yes & Yes & - & - \\
\hline Wild male & Diploid & 12 & 87 & 5.4 & 17.6 & - & Yes & Yes & - & - \\
\hline Farmed male & Triploid & 13 & 86 & 7.1 & 19.8 & - & Yes & Yes & - & - \\
\hline Farmed male & Triploid & 14 & 89 & 6.5 & 18.9 & - & Yes & No & - & - \\
\hline Farmed male $^{\mathrm{a}}$ & Triploid & 15 & 79 & nd & 20.0 & - & Yes & No & - & - \\
\hline Farmed male & Triploid & 16 & 75 & nd & 20.2 & - & Yes & No & - & - \\
\hline
\end{tabular}
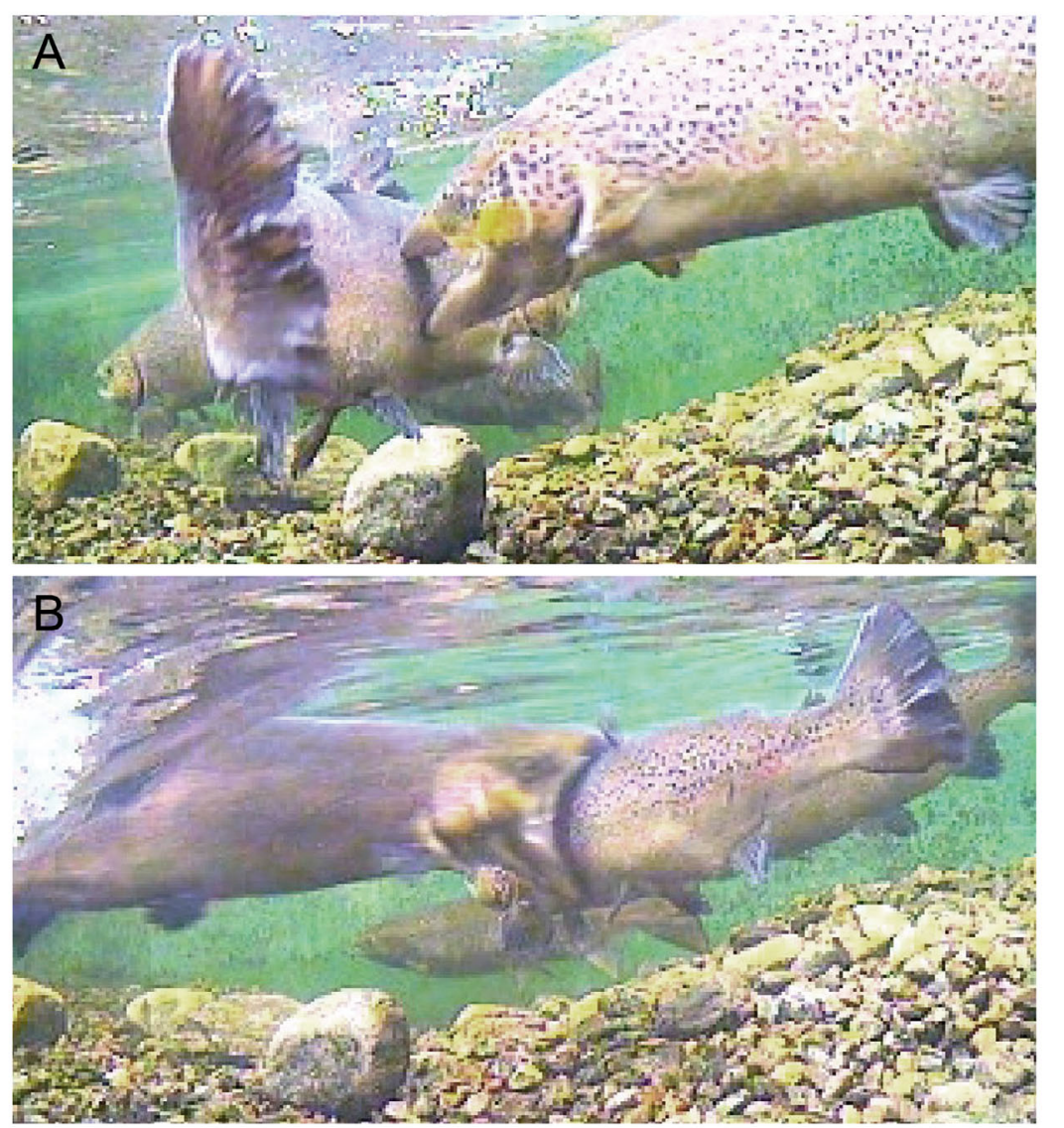

Fig. 1. Triploid male aggression (Arena 1). Triploid male (A) attacking and (B) biting laterally at the trunk region of another triploid male. The wild female can be spotted in the nest close to the wall of the arena in both $\mathrm{A}$ and $\mathrm{B}$
(Fish 1) was resting in the nest. As the wild female (Fish 1) dug her nest (Fig. 2B), 2 of the triploid males (Fish 3 and 6) were continuously changing position from in front of to behind the nest. At $14: 35 \mathrm{~h}$, one of these triploid males (Fish 3) displayed quivering behavior, a courting display whereby he vibrated his body next to that of the wild female on her nest (Fig. 2C). Ejaculation of milt was observed during quivering. At $15: 15 \mathrm{~h}$, this male (Fish 3) moved away from the nest, while the wild female remained present. At 16:00 $h$, the wild female had moved out of the nest and was swimming together with the 2 courting triploid males. By 22:00 h, the nest was unchanged. The farmed female (Fish 2) and a triploid male (Fish 5) swam close together and alone, close to the inlet pipe, all day.

In Arena 2, the males did not display aggressive behavior during the morning of Day 1 and the wild female (Fish 9), farmed female (Fish 10), 1 triploid male (Fish 14) and 1 wild male (Fish 12) rested passively together. The wild female (Fish 9), however, started to dig at $13: 30 \mathrm{~h}$, at which point 

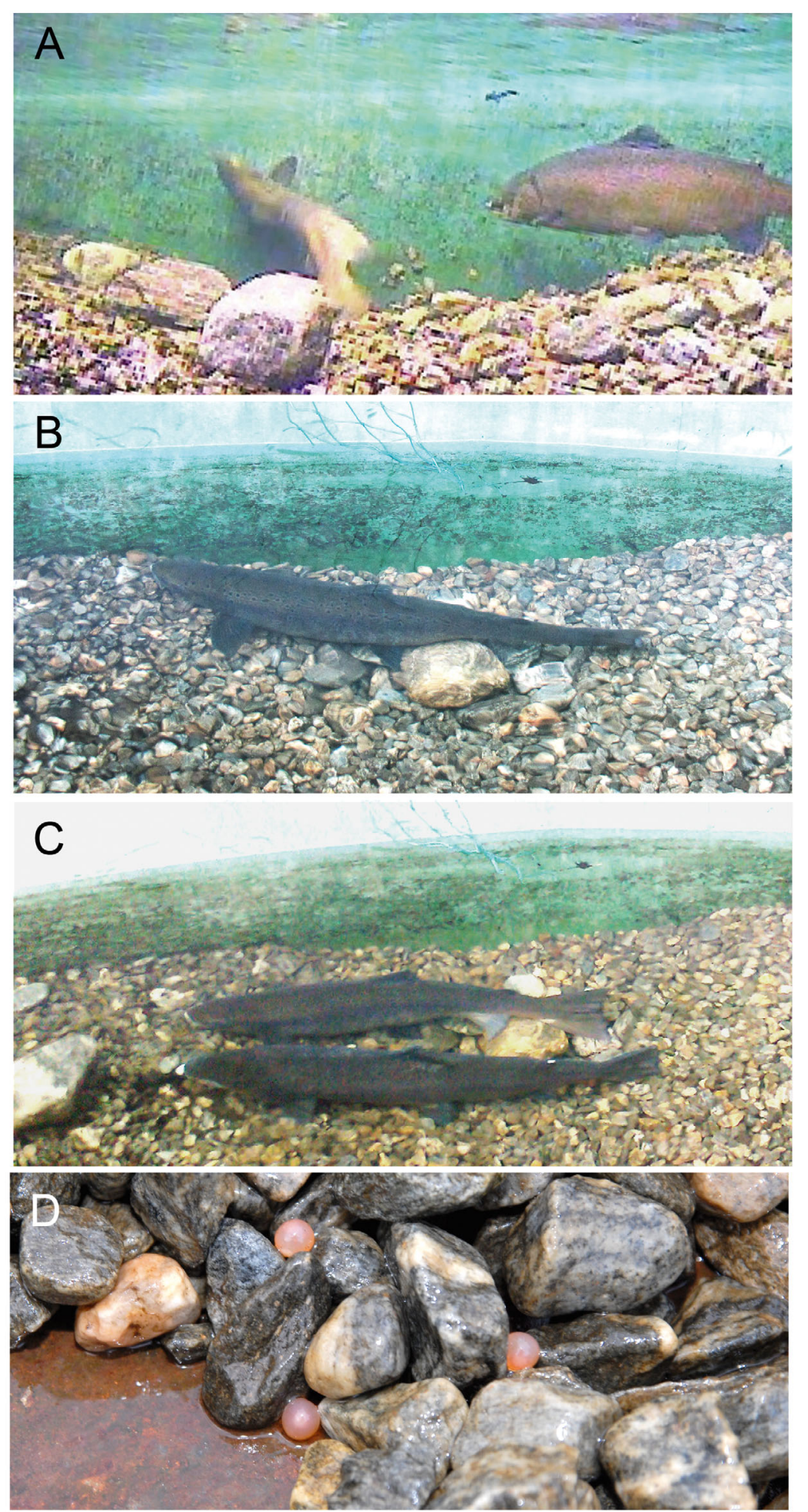

Fig. 2. Triploid male and wild female spawning behavior (Arena 1). (A) Wild female digging nest with triploid male in attendance. (B) Wild female alone in newly made nest. (C) Triploid male courting wild female (black lateral band running along her mid-body) in nest. This triploid male quivered (a courting display) on multiple occasions, whereby he vibrated his body next to that of the wild female. (D) Eggs deposited in the gravel by the wild female in the arena stocked with triploid males only the wild males (Fish 11 and 12) also started to be more active. Although she was digging, she was not resting in the nest during the daylight hours on Day 1 ; the wild female (Fish 9) swam beside the nest, with the 2 wild males (Fish 11 and 12) in front of the nest. By 22:00 h, the nest was covered with gravel, and there was also evidence of a new nest developing in front of the covered nest.

16 November (Day 2). In Arena 1, the nest had become slightly larger and the 2 courting triploid males (Fish 3 and 6) from the day before, plus 1 new triploid male (Fish 4), were fighting until 13:00 h, when the fish started to behave less aggressively towards each other. Here the male (Fish 3) that quivered with the wild female the previous day and the new male (Fish 4) showed the most aggression against each other. The farmed female (Fish 2) and a triploid male (Fish 5) swam close together and alone, close to the inlet pipe, all day. They occasionally made short 'trips' in the arena, but were always close and returned to the inlet pipe.

In Arena 2, there was no spawning activity; the wild female (Fish 9) rested in front of her second nest, with 1 triploid male (Fish 13) in front of her and the 2 wild males (Fish 11 and 12) behind the nest. The triploid male (Fish 13) showed some mild aggression (chasing) against the 2 wild males (Fish 11 and 12). At 15:00 $\mathrm{h}$, we inspected the nest that appeared to have been completed on Day 1 by carefully removing some gravel. Eggs were found in the gravel, demonstrating that spawning had occurred in this nest during the night between Days 1 and 2.

17 November (Day 3). In Arena 1, the nest had not changed during the previous night. There was no activity in this arena on Day 3; the wild female (Fish 1) was on the nest, and the triploid males did not show courtship behavior towards her. The male that displayed the most aggressive behavior on Day 2 (Fish 4) and the 2 males (Fish 3 and 6) courting the wild female on Day 1 plus 1 new triploid male (Fish 5) swam passively behind the 
wild female during all of Day 3. The farmed female (Fish 2) swam mostly alone by the inlet pipe on Day 3.

In Arena 2, there had been no changes in the nest, and the fish occasionally changed position and were passive during much of the day.

18 November (Day 4). At 10:00 h, all females were carefully netted out and checked for ovulation status. Both the wild and farmed females had ovulated in both arenas. After checking the ovulation status, 2 new triploid males (Fish 7, 8, 15 and 16) were stocked into each of the spawning areas, all with running milt.

19 November (Day 5). In Arena 1, the wild female had made a second (new) nest behind the old nest. She rested in the new nest during the day, and also started to dig one more nest behind the old nest at 13:00 h. The amount of aggression by the triploid males increased during the day. There was no spawning activity in Arena 2 this day.

20 November (Day 6). In Arena 1, the second nest of the wild female had been covered with gravel. There was not much spawning activity during the daylight hours this day

In Arena 2, a new nest behind the old nest was detected. There was not much spawning activity during the daylight hours this day.

21 November (Day 7). In Arena 1, the nest that was observed to have been covered with gravel the previous day was inspected and eggs were found in the gravel (Fig. 2D), indicating that spawning had taken place during the night between 19 and 20 November. The farmed female (Fish 2) had still not shown any signs of spawning activity.

In Arena 2, the wild (Fish 9) and farmed (Fish 10) females were observed digging beside each other.

\section{General observations from the entire study period}

The wild females spawned in both arenas. Although they had both ovulated when stocked into the spawning areas, and started to dig a nest on Day 1, the female in Arena 2 spawned 4 d earlier than the female in Arena 1. Also, the farmed females reacted differently in the 2 spawning arenas. The farmed female in Arena 1 did not show any nesting or spawning behavior during the study period, despite being fully ovulated. The farmed female in Arena 2 spawned several times during the study period, and had only a few remaining eggs in her body cavity at termination of the study. Regarding male aggression, there was considerably more aggression between males in Arena 1, with only triploid males, compared with Arena 2, with both triploid and wild diploid males; the male aggression in Arena 1 included long periods of fighting and biting, while the male aggression in Arena 2 was much milder and was mostly chasing and displays. Although all triploid males (Fish 13-16) in Arena 2 showed short periods of courting behavior with either the wild or the farmed female, only one of them (Fish 13) showed aggressive behavior, attempting to chase the wild males (Table 1).

\section{DISCUSSION}

This study has demonstrated, for the first time, that (1) triploid male Atlantic salmon can display the full range of spawning behaviors shown by sexually mature diploid wild males, and (2) wild females will spawn with triploid wild salmon, even in the absence of a diploid male. These results have implications for the potential use of triploid salmon in commercial salmon farming.

The Atlantic salmon aquaculture industry has grown rapidly in the 4 decades or so in which it has existed, and is set to continue to develop. Nevertheless, there is a range of environmental challenges that this rapid expansion has caused. Mitigating genetic interactions between farmed escapees and wild conspecifics is ideally carried out by stopping the escape of farmed fish, or by removing them from the wild prior to reproduction. However, it is unlikely that escapes will cease completely as long as the industry continues to use cage culture, and complete recapture of farmed escapees is similarly unlikely. Thus, the production of sterile salmon for farming represents a potentially attractive way in which further introgression of farmed salmon into native populations (Skaala et al. 2006, Glover et al. 2012, 2013) can be halted. Nevertheless, farmed Atlantic salmon also display ecological interactions with wild salmon (Jonsson \& Jonsson 2006), and disruption of spawning or, potentially worse, coaxing of wild females to spawn with sterile males represents a potential problem, particularly where escapees outnumber wild fish on the spawning grounds, as has been observed periodically in some rivers (Fiske et al. 2006).

This study has demonstrated the potential for triploid farmed males to disrupt wild salmon spawning; however, the quantitative aspects of this, such as the frequency of triploid salmon that display these behaviors and the competitive ability of the triploid salmon to outcompete wild males, still require further elucidation. Although the lower recapture rates at return to river of triploid than diploid salmon grilse (Cotter et 
al. 2000) are indicative of lower seawater survival, they may also reflect greater straying and/or older age at sexual maturity in triploids. Indeed, male triploid farmed salmon seem to have lower incidences of early sexual maturation (post-smolt and grilse) compared with diploids (P. G. Fjelldal pers. obs.). However, the degree to which triploid farmed males mature after 2 or more years in seawater remains to be studied. Late maturity, at large body size, in triploid males could make them more successful during competition for females on natural spawning grounds. Potentially, production of all-female triploids would be the most beneficial solution to avoid wild-farmed fish interaction during spawning. However, some immature triploid females may enter rivers (Cotter et al. 2000); whether these females will display any spawning behavior remains to be studied. Interestingly, the Environment Agency in the UK has decided to only permit fisheries to stock female triploid brown trout Salmo trutta or the progeny of local brood-stock reared under a suitable regime from 2015.

The triploid male Atlantic salmon used in the present study had running milt and showed spawning behavior, while Kitamura et al. (1991) found that mature triploid male Masu salmon showed spawning behavior with diploid females without having running milt. Cotter et al. (2000) compared fertilization success in diploid and triploid male Atlantic salmon, and found that $1.6 \%$ of the fry survived until first feeding in a triploid male $\times$ diploid female cross, compared with $92.7 \%$ for a diploid male $\times$ diploid female cross. Although survival after first feeding was not examined in that study, yolk sack absorption was poor in the surviving triploids with low prospects of further survival. The reason why fry from a diploid female $\times$ triploid male cross do not survive well is that the DNA content of triploid sperm is intermediate between haploid and diploid (1.46 n), making the offspring aneuploid with an average ploidy level of $2.42 \mathrm{n}$ (Peruzzi et al. 2009).

In the present study, both the wild and the farmed female appeared more responsive to spawning in the arena with wild males. Both the farmed and the wild female spawned in Arena 2, and the wild female in Arena 1 spawned 4 d later than the wild female in Arena 2, after introducing new triploid males. It is not clear whether this was a function of male ploidy or wild/farmed status given the present study design; no diploid farmed males were present in the spawning arenas. Furthermore, the lack of replication in the present study cannot rule out the possibility that differences between treatments reflected differences in individual characteristics.
Acknowledgements. We thank Dr. Ole Folkedal at the Institute of Marine Research for helping to set up cameras. The present study was conducted under the Norwegian Research Council funded project INTERACT.

\section{LITERATURE CITED}

Anonymous (2007) Scottish Fish Farms Annual Production Survey 2007. Fisheries Research Services, Marine Laboratory, Aberdeen, Scotland, UK. Available at www.marlab.ac.uk/FRS.Web/Uploads/Documents/surveytext2007 final.pdf.

Anonymous (2012) Oppdaterte rømmingstall. Fiskeridirektorated, Bergen. Available at www.fiskeridir.no/statistikk/ akvakultur/oppdaterte-roemmingstall (in Norwegian)

Bourret V, O'Reilly PT, Carr JW, Berg PR, Bernatchez L (2011) Temporal change in genetic integrity suggests loss of local adaptation in a wild Atlantic salmon (Salmo salar) population following introgression by farmed escapees. Heredity 106:500-510

Butler JRA, Cunningham PD, Starr K (2005) The prevalence of escaped farmed salmon, Salmo salar L., in the River Ewe, western Scotland, with notes on their ages, weights and spawning distribution. Fish Manag Ecol 12:149-159

Clifford SL, McGinnity P, Ferguson A (1998) Genetic changes in Atlantic salmon (Salmo salar) populations of northwest Irish rivers resulting from escapes of adult farm salmon. Can J Fish Aquat Sci 55:358-363

Cotter D, O'Donovan V, Ó Maoiléidigh N, Rogan G, Roche N, Wilkins NP (2000) An evaluation of the use of triploid Atlantic salmon (Salmo salar L.) in minimising the impact of escaped farmed salmon on wild populations. Aquaculture 186:61-75

Crozier WW (1993) Evidence of genetic interaction between escaped farmed salmon and wild Atlantic salmon (Salmo salar L) in a Northern Irish river. Aquaculture 113:19-29

FAO (2013) Cultured aquatic species information programme. FAO, Rome. Available at www.fao.org/fishery/culturedspecies/Salmo_salar/en

Feindel NJ, Benfey TJ, Trippel EA (2010) Competitive spawning success and fertility of triploid male Atlantic cod Gadus morhua. Aquacult Environ Interact 1:47-55

Ferguson A, Fleming IA, Hindar K, Skaala Ø, McGinnity $\mathrm{P}$, Cross T, Prodohl P (2007) Farm escapees. In: Verspoor E, Stradmeyer L, Nielsen JL (eds) The Atlantic salmon: genetics, conservation and management. Blackwell, Oxford, p 357-398

Fiske P, Lund RA, Hansen LP (2006) Relationships between the frequency of farmed Atlantic salmon, Salmo salar L., in wild salmon populations and fish farming activity in Norway, 1989-2004. ICES J Mar Sci 63:1182-1189

- Fleming IA (1996) Reproductive strategies of Atlantic salmon: ecology and evolution. Rev Fish Biol Fish 6:379-416

Fleming IA, Einum S (1997) Experimental tests of genetic divergence of farmed from wild Atlantic salmon due to domestication. ICES J Mar Sci 54:1051-1063

> Fleming IA, Jonsson B, Gross MR, Lamberg A (1996) An experimental study of the reproductive behaviour and success of farmed and wild Atlantic salmon (Salmo salar). J Appl Ecol 33:893-905

Fleming IA, Hindar K, Mjolnerod IB, Jonsson B, Balstad T, Lamberg A (2000) Lifetime success and interactions of farm salmon invading a native population. Proc R Soc Lond B Biol Sci 267:1517-1523 
Fraser TWK, Hansen T, Skjæraasen JE, Mayer I, Sambraus F, Fjelldal PG (2013) The effect of triploidy on the culture performance, deformity prevalence, and heart morphology in Atlantic salmon. Aquaculture 416-417: 255-264

Garcia de Leaniz C, Fleming IA, Einum S, Verspoor E and others (2007) A critical review of adaptive genetic variation in Atlantic salmon: implications for conservation. Biol Rev Camb Philos Soc 82:173-211

Gjedrem T, Gjoen HM, Gjerde B (1991) Genetic origin of Norwegian farmed Atlantic salmon. Aquaculture 98: 41-50

- Glover KA (2010) Forensic identification of fish farm escapees: the Norwegian experience. Aquacult Environ Interact 1:1-10

> Glover KA, Skilbrei OT, Skaala O (2008) Genetic assignment identifies farm of origin for Atlantic salmon Salmo salar escapees in a Norwegian fjord. ICES J Mar Sci 65: 912-920

> Glover KA, Ottera H, Olsen RE, Slinde E, Taranger GL, Skaala O (2009) A comparison of farmed, wild and hybrid Atlantic salmon (Salmo salar L.) reared under farming conditions. Aquaculture 286:203-210

Glover KA, Quintela M, Wennevik V, Besnier F, Sørvik AGE, Skaala O (2012) Three decades of farmed escapees in the wild: a spatio-temporal analysis of population genetic structure throughout Norway. PLoS ONE 7: e43129

Glover KA, Pertoldi C, Besnier F, Wennevik V, Kent M, Skaala Ø (2013) Atlantic salmon populations invaded by farmed escapees: quantifying genetic introgression with a Bayesian approach and SNPs. BMC Genet 14:74

$>$ Jensen $\varnothing$, Dempster T, Thorstad EB, Uglem I, Fredheim A (2010) Escapes of fishes from Norwegian sea-cage aquaculture: causes, consequences and prevention. Aquacult Environ Interact 1:71-83

> Jonsson B, Jonsson N (2006) Cultured Atlantic salmon in nature: a review of their ecology and interaction with wild fish. ICES J Mar Sci 63:1162-1181

Karlsson S, Moen T, Lien S, Glover KA, Hindar K (2011) Generic genetic differences between farmed and wild Atlantic salmon identified from a 7K SNP-chip. Mol Ecol Resour 11:247-253

Kitamura S, Ogata H, Onozato H (1991) Triploid male masu salmon Oncorhynchus masou normal courtship behaviour. Bull Jpn Soc Sci Fish 57:1657-1660

Lund RA, Hansen LP (1991) Identification of wild and reared Atlantic salmon, Salmo salar L., using scale characters. Aquacult Fish Manag 22:499-508

> Lura H, Saegrov H (1991) Documentation of successful spawning of escaped farmed female Atlantic salmon, Salmo salar, in Norwegian rivers. Aquaculture 98:151-159

> McGinnity P, Prodohl P, Ferguson K, Hynes R and others (2003) Fitness reduction and potential extinction of wild populations of Atlantic salmon, Salmo salar, as a result of interactions with escaped farm salmon. Proc R Soc Lond B Biol Sci 270:2443-2450

> Milner NJ, Evans R (2003) The incidence of escaped Irish farmed salmon in English and Welsh rivers. Fish Manag Ecol 10:403-406

> Morris MRJ, Fraser DJ, Heggelin AJ, Whoriskey FG, Carr JW, O'Neil SF, Hutchings JA (2008) Prevalence and

Editorial responsibility: Dean Jerry,

Townsville, Australia recurrence of escaped farmed Atlantic salmon (Salmo salar) in eastern North American rivers. Can J Fish Aquat Sci 65:2807-2826

> Naylor R, Hindar K, Fleming IA, Goldburg R and others (2005) Fugitive salmon: Assessing the risks of escaped fish from net-pen aquaculture. Bioscience 55:427-437

> Peruzzi S, Rudolfsen G, Primicerio R, Frantzen M, Kauric G (2009) Milt characteristics of diploid and triploid Atlantic cod (Gadus morhua L.). Aquacult Res 40:1160-1169

Roberge C, Einum S, Guderley H, Bernatchez L (2006) Rapid parallel evolutionary changes of gene transcription profiles in farmed Atlantic salmon. Mol Ecol 15:9-20

Saegrov H, Hindar K, Kalas S, Lura H (1997) Escaped farmed Atlantic salmon replace the original salmon stock in the River Vosso, western Norway. ICES J Mar Sci 54: 1166-1172

Skaala Ø, Hoyheim B, Glover K, Dahle G (2004) Microsatellite analysis in domesticated and wild Atlantic salmon (Salmo salar L.): allelic diversity and identification of individuals. Aquaculture 240:131-143

Skaala Ø, Wennevik V, Glover KA (2006) Evidence of temporal genetic change in wild Atlantic salmon, Salmo salar L., populations affected by farm escapees. ICES J Mar Sci 63:1224-1233

Skaala Ø, Glover Kevin A, Barlaup Bjørn T, Svåsand T, Besnier F, Hansen Michael M, Borgstrøm R (2012) Performance of farmed, hybrid, and wild Atlantic salmon (Salmo salar) families in a natural river environment. Can J Fish Aquat Sci 69:1994-2006

Solberg MF, Kvamme BO, Nilsen F, Glover KA (2012) Effects of environmental stress on mRNA expression levels of seven genes related to oxidative stress and growth in Atlanic salmon Salmo salar L. of farmed, hybrid and wild origin. BMC Res Notes 5:672

Solberg MF, Skaala Ø, Nilsen F, Glover KA (2013) Does domestication cause changes in growth reaction norms? A study of farmed, wild and hybrid Atlantic salmon families exposed to environmental stress. PLoS ONE 8: e54469

Taylor EB (1991) A review of local adaptation in salmonidae, with particular reference to Pacific and Atlantic salmon. Aquaculture 98:185-207

> Taylor JF, Sambraus F, Mota-Velasco J, Guy DR and others (2013) Ploidy and family effects on Atlantic salmon (Salmo salar) growth, deformity and harvest quality during a full commercial production cycle. Aquaculture 410411:41-50

Thorstad EB, Fleming IA, McGinnity P, Soto D, Wennevik V, Whoriskey F (2008) Incidence and impacts of escaped farmed Atlantic salmon, Salmo salar, in nature. Report from the Technical Working Group on Escapes of the Salmon Aquaculture Dialogue, World Wildlife Fund

> Walker AM, Beveridge MCM, Crozier W, Ó Maoiléidigh N, Milner N (2006) Monitoring the incidence of escaped farmed Atlantic salmon, Salmo salar L., in rivers and fisheries of the United Kingdom and Ireland: current progress and recommendations for future programmes. ICES J Mar Sci 63:1201-1210

Webb JH, Hay DW, Cunningham PD, Youngson AF (1991) The spawning behavior of escaped farmed and wild adult Atlantic salmon (Salmo salar L) in a Northern Scottish river. Aquaculture 98:97-110

Submitted: December 27, 2013; Accepted: April 1, 2014 Proofs received from author(s): June 11, 2014 